\title{
THE ROLE OF ATTORNEY FEE SHIFTING IN PUBLIC INTEREST LITIGATION
}

\author{
Robert V. Percival* and Geoffrey P. Miller $\dagger$
}

\section{INTRODUCTION}

The most significant exception to the "American Rule" that civil litigants bear their own attorney fees occurs in cases where a statute expressly authorizes a court award of attorney fees. ${ }^{1}$ More than 150 federal statutes now authorize attorney fee shifting ${ }^{2}$ and certain state statutes also authorize fee shifting. ${ }^{3}$ Most American fee shifting statutes permit fee awards to successful plaintiffs in order to encourage litigation deemed to be in the public interest. ${ }^{4}$ Among the most important federal fee shifting statutes are the Civil Rights Attorneys' Fees Awards Act of $1976^{5}$ and the Equal Access to Justice Act $^{6}$ which permit attorney fees awards to prevailing parties in broad classes of civil rights litigation and in litigation against the federal government. $^{7}$

As court awards of attorney fees to plaintiffs in civil rights, environmental, and consumer cases became more frequent, proposals surfaced to place generic restrictions on attorney fees awards. The Reagan Administration and representatives of

Copyright (C) 1984 by Law and Contemporary Problems

* Senior Attorney, Environmental Defense Fund. The views expressed herein are my own and do not necessarily represent the position of the Environmental Defense Fund

$\dagger$ Assistant Professor of Law, University of Chicago Law School.

1. The history of the "American Rule" is outlined in detail in Justice White's majority opinion in Alyeska Pipeline Co. v. Wilderness Soc'y, 421 U.S. 240 (1975).

2. Ruckelshaus v. Sierra Club, 103 S. Ct. 3274 (1983). For a list of federal statutes authorizing attorney fee awards, see ATT'Y FEe AwARDS REP., Apr. 1982, at 2. Most of the statutes authorizing fee shifting were enacted after the Supreme Court's decision in Alyeska Pipeline Co. v. Wilderness Soc'y, 421 U.S. 240 (1975). Many federal statutes, however, expressly authorized attorney fee awards at the time Alyeska was decided. Id. at 260 n.33.

3. See, e.g., Calif. Civ. Proc. Code $\S 1021.5$ (West 1982), which gives California courts authority to award attorney fees in actions to enforce "important" rights in the public interest that confer a "significant benefit" on "a large class of persons."

4. See Derfner, The True American Rule: Drafing Fee Legislation in the Public Interest, 2 W. New ENG. L. Rev. 251 (1979); R. Larson, Federal Court Awards Of Attorneys' Fees (1981).

5. 42 U.S.C. $\S 1988(1976)$.

6. 5 U.S.C. $\$ 504(1982)$.

7. The Civil Rights Attorneys' Fees Awards Act authorizes attorney fees awards to the prevailing party in any action to enforce a provision of the Reconstruction Civil Rights Acts, Title VI of the Civil Rights Act of 1964, and Title IX of the Education Amendments of 1972. See Derfner, The Civil Rights Altomeys' Fees Awards Acl of 1976, in Public InTerest Practice \& Fee Awards (H. Newberg ed. 1980). The Equal Access to Justice Act permits attorney fees awards against the United States to the same extent as against any other party under the common law or any statute authorizing attorneys' fee awards and also allows a fee recovery by prevailing parties meeting special eligibility requirements unless the government can show that its position was substantially justified. See OfFICE OF LEGAL POLICY, U.S. DePT. Of Justice, Award of Attorney Fees and Other Expenses in Judicial Proceedings Under the Equal ACCESS TO JUSTICE ACT (1981). 
state and local governments, for example, have promoted legislation that would severely limit recovery of attorney fees. ${ }^{8}$ While proponents of these proposed restrictions maintain that they are necessary to correct abuses, virtually no data supports their claim that excessive fees regularly are being awarded under existing statutes. The real goal of the proposed restrictions is to discourage public interest litigation by reducing both the likelihood of recovering attorney fees and the amount of such recoveries.

This article considers proposals to restrict attorney fees awards in light of the goals of fee shifting statutes and the role they play in public interest litigation. The nature of public interest activity and the economic rationale for encouraging it are discussed first. The role fee shifting statutes play in encouraging public interest litigation is examined next. Details of the proposed restrictions on fee awards are then outlined and discussed.

\section{II}

\section{The Rationale for Encouraging Public Interest Activity}

Before examining the role fee shifting statutes play in public interest litigation, it is important to discuss what actions are considered "public interest activity" and why society can benefit from encouraging such activity.

\section{A. The Nature of Public Interest Activity}

The term "public interest" is used in many different contexts to describe and justify a wide variety of policies and activities. ${ }^{9}$ While agreement is unlikely on a single definition of public interest, inherent in the concept of public interest activity is the notion of action benefitting a larger group than the individual or group responsible for the activity. ${ }^{10}$ Activity primarily benefitting the individual actor can be considered private interest activity, while activity producing wider benefits is more likely to have a public interest character.

Because actions may benefit both the actor and a wider group, there is no clear-cut dichotomy between "public interest" or "private interest" activities. In his economic analysis of the public interest sector, Burton Weisbrod ranked the

8. The original Reagan Administration draft proposal was entitled The Limitation of Legal Fees Awards Act of 1981 [hereinafter cited as the 1981 Reagan Proposal]. It died without a sponsor. A new proposal, styled the Legal Fees Reform Act [hereinafter cited as the 1983 Reagan Proposal], has been drafted by the U.S. Department of Justice but has not been released publicly. For other proposals to restrict attorney fee awards, see Attomeys' Fees Awards: Hearings on $S .585$ before the Subcomm. on the Constitution of the Senate Judiciary Comm., 97th Cong., 2d Sess. 12-13 (1982) [hereinafter cited as Hearings] (Limitation on Awards of Altomeys' Fees and Other Costs, amendment to S. 585 to be proposed by Senator Hatch); Id. at 91-101 (testimony of James B. Brennan, National Institute of Municipal Law Officers). For further discussion of these proposals, see infra notes $57-71$ and accompanying text.

9. See, e.g., Downs, The Public Interest: Its Meaning in a Democracy, SOC. Research, Spring 1962, at 5; G. Schubert, The Public Interest (1960); Nomos V: The Public Interest (C. Friedrich ed. 1962).

10. See Weisbrod, Conceptual Perspective on the Public Interest: An Economic Analysis, in PUBLIC INTEREST LaW: AN ECONOMIC and Institutional ANALysis 420 (B. Weisbrod ed. (1978)) [hereinafter cited as PUBLIC INTEREST LAW], which defines "a public interest activity as one that, if it is successful, will bring about significant external gross benefits to some persons; that is, the activity provides more complete representation for some interest that is underrespresented in the sense that the interest has not been fully transmitted through either the private market or governmental channels." 
public interest character of activities along a continuum based on the ratio of expected external benefits (benefits enjoyed by parties other than the actor) to expected total benefits (sum of external and internal benefits): ${ }^{11}$

$$
\text { P.I. Ratio }=\frac{\text { External }+ \text { Internal Benefits }}{\text { External Benefits }} .
$$

The greater the value of benefits accruing to persons outside the acting group (external benefits) relative to benefits reaped by members of the group (internal benefits), the greater is the public interest character of the activity in Weisbrod's scheme.

\section{B. Public Interest Activity as a Response to Market Failures}

Economists have long recognized that a free market system is not likely to maximize economic welfare due to the existence of market imperfections such as externalities and the problem of producing collective goods. ${ }^{12}$ Government intervention in the marketplace may attempt to correct market imperfections; however, government action alone cannot correct all market imperfections and in some cases may actually exacerbate them. Public interest activity by nongovernmental actors may improve economic welfare by supplementing government action to correct these market failures.

1. Private Market Imperfections. It is well-recognized by economists that under certain real world circumstances, the private market system cannot be expected to produce an efficient allocation of resources. ${ }^{13}$ The classic example of market failure in the environmental area is the problem of externalities. Externalities occur when the costs or benefits of one's actions are not fully internalized to the actor, but rather are borne or are enjoyed by others. ${ }^{14}$ For example, if a factory pollutes the air or water to produce a product more cheaply, the price of the product will not reflect its true social cost because part of the cost (the pollution) will be borne by those who breathe the air or drink the water around the factory. More goods and more pollution will be produced than is economically optimal in the absence of action to internalize the cost of the pollution.

Another failure of private markets is the underproduction of goods whose benefits inevitably are enjoyed by wide segments of society. ${ }^{15}$ In the absence of collective action, private markets will not produce sufficient quantities of public goods, such as national defense or police protection. Similarly, a competitive market system will not necessarily allocate resources in an equitable manner. ${ }^{16}$ Collective action may be desirable to redistribute resources in a manner more equitable than that produced by private markets.

2. Government Action. Government can play a major role in correcting imperfec-

11. Id. at 21 .

12. See generally A. Pigou, The Economics of Welfare (1920) (discussion of market imperfections).

13. See, e.g., Bator, The Anatomy of Market Failure, 52 Q.J. ECON. (1958).

14. See A. Pigou, supra note 12 .

15. See Weisbrod, supra note 10, at 13-14.

16. Id. at 16-17. 
tions in private markets. Through the use of its taxing and spending powers and its other regulatory authorities, government can purchase public goods, help internalize externalities, and redistribute resources in a more equitable manner than the private market system.

Government action cannot, however, be expected to correct all market imperfections. ${ }^{17}$ The one-person, one-vote model of a democratic system suggests that a democratic government responds to somewhat different demands than a onedollar, one-vote market system. Yet, the influence of money in politics ${ }^{18}$ and the varying degrees of organization and political influence possessed by various interest groups imply that a democratic government will not always act to improve economic welfare. Moreover, even after legislation designed to correct imperfections is enacted, it may not be administered or enforced in an optimal manner. Enforcement resources are limited and may be subject to pressures not directed toward maximizing economic and social welfare.

3. Public Interest Activity. Like government action, public interest activity by private actors can improve economic and social welfare by correcting market imperfections. Because the private sector does not possess the regulatory authority available to the government, its ability directly to correct market imperfections is more limited. Thus, public interest activitity by private parties usually involves efforts to stimulate or to supplement action by governmental bodies.

A wide variety of private actors and organizations engage in public interest activity of the type outlined above. Although profit-making organizations can engage in public interest activity, organizations primarily devoted to the public interest are concentrated in the voluntary nonprofit sector. ${ }^{19}$

Many kinds of actions may constitute public interest activity. Public interest organizations litigate, lobby, participate in administrative proceedings, conduct research, gather information, educate the public, and provide community services. ${ }^{20}$ Each of these activities may be public interest activity to the extent that it generates external benefits. While the focus of this article is on public interest litigation and how it is affected by attorney fee shifting, it is important to remember that public interest groups also engage in a variety of nonlitigation activities to promote the public interest.

Because public interest activities by their very nature are directed toward producing benefits that accrue to broad segments of the public, private individuals have fewer incentives to spend their own time and money on such activities.

17. For an extended discussion of governmental failures to correct market imperfections, see id. at 30 41 .

18. See E. Drew, Politics And Money (1983).

19. See Weisbrod, supra note 10 , at 21 .

20. In 1976, the National Inventory of Public Interest Law Programs, maintained by the Council for Public Interest Law, listed 72 public interest law firms that employed a total of 478 lawyers and 384 nonlawyer professionals including researchers, writers, scientists, lobbyists, and administrators. Handler, Ginsberg \& Snow, The Public Interest Law Industry, in Public INTERest LAW, supra note 10, at 51. It estimated that, when mixed private-public interest law firms and legal services backup centers were included, there were a total of 166 firms in the public interest law industry, as well as 5,322 public interest nonlaw organizations. Id. at 76 . 
Organizations have been formed that are devoted to public interest activity and are funded by voluntary contributions. Government has recognized the benefits of public interest activity by private organizations and has acted to encourage it in certain respects. Organizations engaging in public interest activity have been afforded tax-exempt status. ${ }^{21}$ In recognition of the benefits of private litigation to enforce statutory and constitutional rights, private rights of action have been created by statute ${ }^{22}$ or judicial implication, ${ }^{23}$ and fee shifting statutes have been enacted to provide an incentive for successful public interest litigation. ${ }^{24}$ The role that fee shifting statutes play in encouraging public interest litigation is explored below.

\section{III}

\section{The Role of Fee Shifting in Public Interest Litigation}

While public interest litigation is funded by a variety of sources, transaction costs and the diffuse nature of the benefits the litigation produces imply that insufficient resources will be devoted to such litigation in the absence of fee shifting. Congress has enacted fee shifting statutes expressly to encourage public interest litigation by removing some of the economic disincentives facing public interest litigants. While attorney fee awards are an important mechanism for encouraging public interest litigation, they continue to represent only a modest source of funding for most public interest organizations.

\section{A. Inadequacy of Economic Incentives}

Most civil litigation is initiated by private parties who possess an interest in the outcome of the litigation sufficient to make litigation worthwhile. ${ }^{25}$ Rational plaintiffs would have to expect to receive legal or equitable relief of sufficient value to compensate them for the expense and risk of litigation.

Private individuals have much weaker economic incentives for engaging in public interest litigation. Because public interest litigation seeks to advance interests shared by broad segments of the public (e.g., environmental protection, civil rights, consumer protection), the benefits of such litigation are widely scattered

21. Section 501 (c) (3) of the Internal Revenue Code affords tax-exempt status to not-for-profit organizations "operated exclusively for religious, charitable, scientific, testing for public safety, literary, or educational purposes." Section $170(\mathrm{c})(2)$ of the Internal Revenue Code makes contributions to such organizations tax deductible. For a discussion of tax considerations affecting public interest organizations, see Post \& Ravikoff, Organizational Support to Fund Environmental Litigation, 6 ENvTL. Arralrs 457 (1978).

22. See, e.g., Noise Control Act, 15 U.S.C. $\$ \S 2619-2620$ (1982); Endangered Species Act, 16 U.S.C. $\$ 1540$ (g) (1982); Marine Protection Research \& Sanctuaries Act, 33 U.S.C. $\$ 1415$ (g) (1976); Clcan Water Act, 33 U.S.C. $\S \S 1365(\mathrm{~g}), 1369$ (1976); Deep Water Port Act of 1974, 33 U.S.C. $\S \S 1515-1516$ (1976); Surface Mining Control \& Reclamation Act, 30 U.S.C. $\$ 1270$ (1978); Resource Conservation \& Recovery Act of 1978, 42 U.S.C. $\$ \S 6972,6967$ (1976); Clean Air Act, 42 U.S.C. $\$ \S 7604,7607$ (1976).

23. See, e.g., Cort v. Ash, 422 U.S. 66 (1975); Tunstall v. Brotherhood of Locomotive Fireman \& Engineman, 323 U.S. 210 (1944); Texas \& P. R. R. v. Rigsby, 241 U.S. 33 (1916).

24. See supra notes 5-7 and accompanying text.

25. The law of standing requires that plantiffs have a sufficient interest to satisfy article III's "cases and controversies" requirement, although this interest can be "aesthetic, conservational, and recreational as well as economic. . . " Association of Data Processing Serv. Orgs. v. Camp, 397 U.S. 150. 154 (1970). 
rather than concentrated in an individual party. ${ }^{26}$ Thus, the prospective benefit to an individual party generally will not be sufficient to make it worthwhile for him to bear the costs of public interest litigation. For this reason, public interest law is often defined as involving efforts to provide legal representation to previously underrepresented groups or interests. ${ }^{27}$ While such a definition could also embrace conventional private litigation undertaken on behalf of persons unable to afford legal fees, the focus here is on litigation that ordinarily would not be undertaken because it generates predominantly external benefits.

The formation of public interest groups funded by voluntary contributions is one means for overcoming some of the disincentives facing the public interest litigant. While voluntary contributions are the principal source of funding for public interest litigation, ${ }^{28}$ they alone cannot produce an economically optimal level of funding because of transaction costs and the inability of public interest groups to collect from all beneficiaries of the litigation. Transaction costs include the often significant expenses involved in identifying and contacting potential donors. ${ }^{29}$ These transaction costs and the problem of "free riders" (individual beneficiaries

26. The guidelines established by the Internal Revenue Service for affording $\$ 501$ (c)(3) tax-exempt status to public interest law firms require that

[t]he engagement of the organization in litigation can reasonably be said to be in representation of a broad public interest rather than a private interest. The litigation is designed to present a position on behalf of the public at large on matters of public interest. Typical of such litigation may be class actions in the public interest, suits for injunction against action by government or private interest broadly affecting the public, similar representation before administrative boards and agencies, test suits where the private interest is small, and the like. The activity would not normally extend to direct representation of litigants in actions between private persons where their financial interests at stake would warrant representation from private legal sources.

Rev. Proc. 71-39, 1971-2 C.B. 575. Public interest law firms generally are barred from accepting fees for their services by the IRS guidelines.

27. In 1976, the Council for Public Interest Law adopted the following definition:

Public interest law is the name that has recently been given to efforts to provide legal representation to previously unrepresented groups and interests. Such efforts have been undertaken in recognition that the ordinary marketplace for legal services fails to provide such services to significant segments of the population and to significant interests. Such groups and interests include the poor, environmentalists, consumers, social and ethnic minorities, and others.

Council for Public Interest Law, Balancing the Scales of Justice 6-7 (1976).

A report on public interest law sponsored by the Ford Foundation in 1973 defined public interest law in the following manner:

Public interest law is the representation of the underrepresented, and the line separating it from poverty and civil rights law can best be defined historically. Broadened social concerns-as in the field of consumer protection and environmental quality - along with a growing body of law expressing those concerns, created new needs for legal actions and legal representation. Since such actions were by definition for the benefit of large classes of people, individuals seldom could afford the cost.

G. Harrison \& S. Jaffe, The Public Interest law Firm; New Voices for New Constituencies 9 (1973)

28. A survey by the Council for Public Interest Law found that in 1975 public interest law organizations received a total of $\$ 34$ million. Of this total, $\$ 14.5$ million came from foundation grants, $\$ 8.6$ million from other contributions and grants, and $\$ 6.3$ million from membership dues. Government provided $\$ 3.1$ million in funds to public interest law organizations while court-awarded fees provided $\$ 600,000$. Settle $\&$ Weisbrod, Financing Public Interest Law: An Evaluation of Alternative Financing Amangements, in PUBLIC INTEREST LAW, supra note 10, at 534.

29. The fact that fund raising expenses may consume a large portion of the budgets of charitable organizations is indicated by the Better Business Bureau's guideline that no more than $40 \%$ of an organization's budget should be devoted to such expenses. BeTter Business BUREAU, PHILANTHROPIC ADVISORY Services, Give But Give Wisely (1983). 
of public interest litigation who enjoy its benefits regardless of whether they make a contribution) ensure that voluntary contributions alone will be inadequate to fund an efficient level of public interest litigation. ${ }^{30}$

\section{B. Fee Shifting as an Incentive to Public Interest Litigation}

The importance of private rights of action as a means of implementing and enforcing public policy has long been recognized in a wide variety of areas. ${ }^{31}$ Where the interests advanced by private litigation vindicate important public policies, Congress often authorizes attorney fee awards to remove some of the disincentives for public interest litigation. Court awards of attorney fees to public interest plaintiffs are designed to encourage public interest litigation, as Congress and the courts repeatedly have reaffirmed.

For example, in the Civil Rights Act of $1964,{ }^{32}$ Congress authorized a private right of action to enjoin discrimination in public accommodations but recognized that this would not be an effective enforcement mechanism in the absence of a provision for attorney fee awards. As the Supreme Court explained in Newman v. Piggie Park Enterprises: 33

When the Civil Rights Act of 1964 was passed, it was evident that enforcement would prove difficult and that the Nation would have to rely in part upon private litigation as a means of securing broad compliance with the law. A Title II suit is thus private in form only. When a plaintiff brings an action under that Title, he cannot recover damages. If he obtains an injunction, he does so not for himself alone, but also as a 'private attorney general,' vindicating a policy that Congress considered of the highest priority. If successful plaintiffs were routinely forced to bear their own attorneys' fees, few aggrieved parties would be in a position to advance the public interest by invoking the injunctive powers of the federal courts. Congress therefore enacted the provision for counsel fees . . . to encourage individuals . . . to seek judicial relief under Title II. ${ }^{34}$

In Alyeska Pipeline Co. v. Wilderness Society ${ }^{35}$ the Supreme Court majority opinion acknowledged that by enacting fee shifting statutes, "Congress has opted to rely heavily on private enforcement to implement public policy and to allow counsel feels so as to encourage private litigation." 36 The Court, however, left it for Congress to decide which public policies are important enough for their private enforcement to be encouraged through authorization of fee shifting. ${ }^{37}$

Justice Marshall, dissenting in Alyeska, proposed three criteria that could be employed by courts in determining whether an award of attorney fees is appropriate in the absence of express statutory authorization:

The reasonable cost of the plaintiff's representation should be placed upon the defendant if

(1) the important right being protected is one actually or necessarily shared by the general

public or some class thereof; (2) the plaintif's pecuniary interest in the outcome, if any, would not normally justify incurring the cost of counsel; and (3) shifting that cost to the

30. See Weisbrod, supra note 10 , at 26 .

31. See supra notes $22-23$ and accompanying text.

32. 42 U.S.C. $\$ 2000$ a (1976).

33. 390 U.S. 400 (1968) (per curiam).

34. Id. at 401-02.

35. 421 U.S. 240 (1975).

36. Id. at 263 .

37. Id. at 264-65. 
defendant would effectively place it on a class that benefits from the litigation. ${ }^{38}$

Under these criteria fee shifting would be permitted in virtually all public interest litigation as defined in this article. Subsequent to Alyeska, Congress took major steps in this direction by authorizing fee shifting in major classes of public interest litigation.

Congress reaffirmed its belief in the importance of fee shifting to encourage public interest litigation when it passed the Civil Rights Attorneys' Fees Awards Act of 1976 in response to the Alyeska decision. The legislative history of the Act clearly illustrates Congress' belief in the importance of private actions to achieve effective enforcement of civil rights laws. The House committee report on the Act notes that the authority and resources of federal agencies charged with civil rights enforcement are limited and that effective enforcement "depends largely on the efforts of private citizens." 39 The legislative history clearly reflects Congress' concern that, in the absence of attorney fee awards, civil rights litigants would suffer severe financial hardship that could deter private enforcement of these laws. Both the Senate and House committee reports note the limited financial resources available to civil rights plaintiffs and the difficulty of obtaining effective representation in the absence of a provision for attorney fee awards. ${ }^{40}$

Most recently, in enacting the Equal Access to Justice Act, ${ }^{41}$ Congress concluded that it was difficult for private plaintiffs to challenge governmental action "because of the expense involved in securing the vindication of their rights in civil actions and administrative proceedings." 42 The purpose of authorizing fee shifting under the Act is to diminish the "deterrent effect" of the expenses faced by parties seeking to challenge government action. ${ }^{43}$ Attorney fee awards under the Act are not limited to public interest litigants. They also are provided for individual or corporate litigants seeking redress of private interests; however, the Act reflects Congress' concern with increasing the access of parties who previously were underrepresented in the adversary process by denying fee awards to parties whose net worth exceeds certain limits. ${ }^{44}$

While Congress has established several different standards of eligibility for attorney fee awards in the various statutes authorizing fee shifting, the most common scheme is a modified one-way shifting in favor of successful plaintiffs. ${ }^{45}$ Differences in fee shifting standards reflect, in part, congressional judgments about the relative importance of encouraging private actions to enforce these statutes. Some statutes authorize attorney fee awards to the "prevailing party," while other

38. Id. at 285-86 (Marshall, J., dissenting).

39. H.R. REP. No. 1558, 94th Cong., 2d Sess. 1 (1976).

40. S. ReP. No. 1011, 94th Cong., 2d Sess. 2-6 (1976); H.R. REP. No. 1558, supra note 39, at 1-4.

41. 5 U.S.C. $§ 504$ (1982).

42. See H.R. ReP No. 1418, 96th Cong., 2d Sess. 9-10 (1980).

43. Id.

44. The Equal Access to Justice Act restricts eligibility for fee awards under its provisions to individuals with a net worth less than $\$ 1,000,000$ and corporations with a net worth less than $\$ 5,000,000$. 5 U.S.C. $\S 504(\mathrm{~b})(1)(\mathrm{B})(1982)$.

45. See Derfner, supra note 4 , at 269. One exception is the fee shifting provision of the Norris LaGuardia Act, 29 U.S.C. $\S 107$ (e) (1976), which permits fee awards only to successful defendants because defendants are the party asserting the important federal rights under the Act. 
statutes, including the Freedom of Information Act, ${ }^{46}$ permit awards to parties who have "substantially prevailed." In Newman v. Piggie Park Enterprises 47 the Supreme Court held that the "prevailing party" standard in the Civil Rights Act of 1964 created a presumption that successful plaintiffs "should ordinarily recover an attorney's fee unless special circumstances would render such an award unjust."48 Recovery for prevailing defendants under this standard has been restricted to cases of "frivolous, unreasonable or groundless" complaints in order not to deter the good faith pursuit of ultimately unsuccessful civil rights actions. ${ }^{49}$

Newman's "prevailing party" standard was adopted by Congress in the Civil Rights Attorneys' Fees Awards Act of 1976.50 The Equal Access to Justice Act employs a modified "prevailing party" standard permitting fee awards to parties who prevail against the government, unless the court finds that the government's position "was substantially justified or that special circumstances make an award unjust." 51

In general, fee shifting statutes provide an incentive only for meritorious litigation because attorney fee awards are authorized only for successful parties. Although some statutes employ a seemingly more liberal standard, by authorizing a court to award attorney fees whenever it determines that such an award is "appropriate," 52 in Ruckelshaus $v$. Sierra Club, ${ }^{53}$ the Supreme Court interpreted this standard to require some measure of success on the merits before a party becomes eligible for a fee award.

Despite differences in the standards employed in the various fee shifting statutes, a reasonably consistent theme runs throughout. Congress generally authorizes fee shifting where private actions serve to effectuate important public policy objectives and where private plaintiffs cannot ordinarily be expected to bring such actions on their own. Fee shifting is designed to remove some of the disincentives facing public interest litigants, thus increasing access to the courts for groups who otherwise might be unrepresented or underrepresented. Use of a modified oneway fee shifting in favor of public interest litigants is expected to achieve these goals. ${ }^{54}$

46. 5 U.S.C. $\$ 552 \mathrm{a}(\mathrm{g})(2)(\mathrm{B})(1982)$.

47. 390 U.S. 400 (per curiam 1968); see supra notes $33-34$ and accompanying text.

48. 390 U.S. at 402 .

49. Christianburg Garment Co. v. EEOC, 434 U.S. 412, 422 (1978).

50. 42 U.S.C. $\$ 1988(1976)$.

51. 5 U.S.C. $\& 504(\mathrm{a})(1)(1982)$.

52. Toxic Substances Control Act, 15 U.S.C. § 2618(d) (1976); Endangered Species Act, 16 U.S.C. $\S 1540(\mathrm{~g})(4)$ (1982); Surface Mining Control and Reclamation Act, 30 U.S.C. $§ 1270$ (d) (Supp. IV 1980); Deep Seabed Hard Mineral Resources Act, 30 U.S.C. \& 1427(c) (Supp. IV 1980); Clean Water Act, 33 U.S.C. § 1365(d) (1976); Marine Protection, Research and Sanctuaries Act, 33 U.S.C. § 1415(g) (4) (1976); Deepwater Port Act, 33 U.S.C. § 1515(d) (1976); Safe Drinking Water Act, 42 U.S.C. § 300 J(8)(d) (1976); Clean Air Act, 42 U.S.C. $\S \S 304$ (d), 307 (f) (1976); Noise Control Act, 42 U.S.C. $§ 4911$ (d) (1976); Energy Policy and Conservation Act, 42 U.S.C. §6305(d) (1976); Powerplant and Industrial Fuel Use Act, 42 U.S.C. § 8435(d) (Supp. IV 1980); Ocean Thermal Energy Conversion Act, 42 U.S.C. § 9124(d) (Supp. IV 1980); Outer Continental Shelf Lands Act, 43 U.S.C. § 1349(a)(5) (Supp. IV 1980).

53. 103 S. Ct. 3274,3276 (1983).

54. See Rowe, Predicting the Effects of Attomey Fee Shifting, Law \& ConTemp. Probs., Winter 1984, at 139; Shavell, Suit, Settlement, and Trial: A Theoretical Analysis under Alternative Methods for the Allocation of Legal Costs, 11 J. Legal Stud. 55, 60-61 (1982). 


\section{IV}

\section{Proposals to Restrict Attorney fee Awards}

In recent years the Reagan Administration and representatives of state and local governments proposed severe generic restrictions on attorney fees awards to public interest litigants. ${ }^{55}$ Proponents of these restrictions maintain that the number and magnitude of attorney fees awards against governmental bodies has been grossly excessive. These proposals are unsupported by data on experience with existing fee shifting statutes, and they ignore the purpose of fee shifting statutes and their impact on public interest litigation.

\section{A. Proposed Restrictions on Fee Awards}

In 1981, the Reagan Administration drafted proposed legislation designed to place severe restrictions on eligibility for attorney fee awards. ${ }^{56}$ The proposed legislation was designed to bar recovery of fee awards against the federal government in most public interest litigation. Under the 1981 Reagan Administration proposal, which would have been applied retroactively to all cases pending at the time of its enactment, public interest organizations that employed staff attorneys in litigation would be prohibited from receiving fee awards. ${ }^{57}$ Fee awards could only be made to private, paying clients in cases handled on a straight-fee basis. ${ }^{58}$ Thus, fees could not be collected in cases handled by private attorneys representing indigent clients or public interest organizations on a pro bono basis. Fee awards would not be permitted to any party represented by a legal services organization that receives funds from the federal government. ${ }^{59}$

Furthermore, the hourly rates for computing fee awards would have been subject to a cap set at the lower of the "actual direct cost" to the party or the highest hourly rates payable to Civil Service attorneys (calculated as $\$ 53.16$ per hour in 1982). ${ }^{60}$ Fee awards would have been permissible only for work performed on issues on which a party actually prevailed and which was necessary for resolving the controversy. ${ }^{61}$ All fee awards in cases where a money judgment was obtained would have been reduced by $25 \%$ of the judgment. ${ }^{62}$ Fees for work performed in litigating fee entitlement issues could be awarded against the government only if the government was unreasonable in its position concerning fee issues. ${ }^{63}$

The 1981 Reagan Administration proposal died without a sponsor. The Administration, however, is now attempting to resuscitate it in modified form. In

55. See supra note 8 and accompanying text.

56. The 1981 Reagan Proposal, supra note 8, drafted by the Office for Management and the Budget, was designed expressly to reduce the amount of attorney fee awards against the federal government and to reduce the federal civil case load. The proposal met such a firestorm of opposition that it never got beyond draft form. The provisions discussed in the text are taken from the last draft of the 1981 Reagan Proposal. A Bill to Provide for the Limitation on Legal Fees Awarded Against the United States (undated draft legislation).

57. 1981 Reagan Proposal, supra note $8, \S 4(\mathrm{a})(3)$.

58. Id. $\S 4(\mathrm{a})(2)$.

59. Id. \$7.

60. Id. § 3(a).

61. Id. $\$ 2$.

62. Id. $\S 6$.

63. Id. $§ 9$. 
1983, the Administration drafted a new proposal which it may seek to introduce in Congress in 1984. The 1983 draft legislation ${ }^{64}$ is much broader in scope than the 1981 proposal because it would apply to fee awards against state and local governmental entities as well as against the federal government. The 1983 proposal, which also applies retroactively to all pending cases, does not contain a flat prohibition on fee awards to public interest organizations using salaried staff attorneys, groups represented by pro bono private counsel, or legal services organizations. It would, however, impose a flat $\$ 75 /$ hour cap on fee awards and permit courts to reduce or deny fees that unreasonably exceed the hourly salary of the attorney performing the work or "the monetary result achieved in the proceeding." 65 The automatic reduction in fees by $25 \%$ of any money judgment is retained in the 1983 draft, ${ }^{66}$ and no "multi-liers" or "bonuses" could be permitted in fee computations. ${ }^{67}$ Fees would only be permitted to parties who were "successful on significant issues in the controversy" and who "obtained significant relief in connection with these issues" 68 - a standard stricter than that reflected in Hensley v. Eckerhart ${ }^{69}$ and Ruckelshaus $v$. Sierra Club. ${ }^{70}$ Fee awards would not be permitted for work performed subsequent to an unreasonably rejected settlement offer if the ultimate relief obtained was not more favorable than the settlement offered. ${ }^{71}$

Other proposed generic restrictions on fee awards include Senator Hatch's proposals. These would limit the hourly rate used in computing fee awards to that prevailing in the local market, bar the use of bonuses and multipliers in fee computations, and deny fees in cases that become moot due to a change in policy unless the pendency of the litigation was the "preponderant reason" for the policy change. ${ }^{72}$

The National Institute of Municipal Law Officers has proposed even more draconian restrictions, including movement toward two-way fee shifting, a ban on fees for work performed in litigating fee entitlement issues, and a requirment that an organizational plaintiff demonstrate that it would not have brought the case but for the availability of the fee award. ${ }^{73}$

64. In its most recent version, which has been drafted and endorsed by the U.S. Department of Justice, the Reagan Administration Proposal is entitled the Legal Fees Reform Act. Although it has not yet been released publicly, Justice Department officials have permitted one of the authors of this article to review the draft legislation.

65. 1983 Reagan Proposal, supra note 8, § 5(a)(1)

66. Id. $\S 5(\mathrm{c})(1)$.

67. Id.

68. Id. $\S 4$.

69. 103 S.Ct. 1933, 1937 (1983). In Hensley v. Eckherhart, the Supreme Court held that a party may be considered a prevailing party for purposes of a fee award if the party prevailed on "any significant issue."

70. 103 S.Ct. 3274, 3276 (1983). In Ruckelshaus v. Sierra Club, the Court held that eligibility for attorneys fees awards under the "where appropriate" standard required "some degree of success on the merits."

71. 1983 Reagan Proposal, supra note 8, § 7(b).

72. See Hearings, supra note 8 , at 12-13.

73. See id. at 91-101 (testimony of James B. Brennan, National Institute of Municipal Law Officers). 


\section{B. Impact of Proposed Restrictions on Public Interest Litigation}

The proposed restrictions on attorney fee awards would significantly reduce the impact of fee shifting statutes in overcoming disincentives to public interest litigation. The original Reagan Administration proposal would have defeated the entire purpose of the fee shifting statutes by permitting fee shifting only to reimburse private litigants who already have resources and a private economic interest in the litigation sufficient to justify hiring private attorneys. This would defeat the very purpose of the fee shifting statutes, which are designed to encourage meritorious public interest litigation. Indeed, the 1981 Reagan Administration proposal was designed expressly to discourage public interest litigation by reducing the incentive effect of fee shifting statutes. ${ }^{74}$

The more recent proposals to restrict fee shifting attempt to justify such restrictions on the theory that fee awards are excessive and unreasonable. This hypothesis is entirely unsupported by the data, and the proposals to correct this alleged "abuse" discriminate against public interest litigants by treating them less favorably than others entitled to fee awards. Courts generally have interpreted fee shifting statutes as applying the same standard for public interest litigants as for other private litigants. The virtually unanimous agreement of lower federal courts that fee awards cannot be denied because of the public interest status of an attorney or organization was confirmed by the Supreme Court in New York Gaslight Club, Inc. v. Carey. ${ }^{75}$ The Court relied in part on the legislative history of the Civil Rights Attorneys' Fees Awards Act, which indicated Congress' intent that public interest attorneys be treated in the same manner as private counsel for purposes of computing fees. ${ }^{76}$

In Copeland v. Marshall, ${ }^{77}$ the Court of Appeals for the District of Columbia adopted a "market value" approach to the computation of attorney fees, rejecting arguments for a cost-plus-profit formula that would treat low-paid public interest attorneys less generously than others. The court acknowledged that the market value approach could provide a public interest firm with a recovery substantially greater than its actual costs. But the court justified this result on the grounds that it would help provide greater enforcement incentives and would avoid distorting the settlement incentive faced by defendants. ${ }^{78}$

The Copeland court also noted that it was easier to compute fees under the market value approach than under the cost-plus method which requires more individualized inquiries into actual litigation expenses. ${ }^{79}$ Several other courts have followed similar reasoning in rejecting attempts to restrict the amount of fees

74. Draft letter to accompany 1981 Reagan Proposal, supra note 8, at 4 ("by restricting attorneys fees, the proposal will decrease Federal outlays and will help reduce the Federal Civil case load, which has grown over $100 \%$ since 1975 . . . .") (on file).

75. 447 U.S. 54 (1980).

76. Id. at 70 n.9.

77. 641 F.2d 880 (D.C. Cir. 1980).

78. Id. at 899 .

79. Id. at 896 . 
awarded public interest litigants. ${ }^{80}$ The Supreme Court is currently considering whether the Civil Rights Attorneys' Fees Awards Act authorizes use of a multiplier and whether a cost-plus method of computation that would compensate public interest attorneys at hourly rates lower than that received by other practitioners should be used. ${ }^{81}$

Proposals imposing caps on hourly rates used in calculating fee awards, eliminating the use of multipliers, and reducing fee awards to public interest groups because of below-market salaries paid to their staff attorneys ${ }^{82}$ tend to defeat the very purpose of fee shifting statutes-overcoming disincentives to public interest litigation. Advocates of proposals prohibiting multipliers and imposing a fee cap argue that such measures will only restrict fee awards to levels commensurate with the salaries of government lawyers. This argument, however, ignores the fact that government lawyers are paid whether or not they prevail and are compensated for all their time, whether or not it is spent on activities for which attorney fees are recoverable. ${ }^{83}$ Attorneys handling public interest cases bear the risk of ultimately not prevailing in the litigation and thus not recovering fees. Moreover, interim fees are rarely paid to public interest attorneys, who may have to wait years before recovering any fees. ${ }^{84} \mathrm{~A}$ prohibition of multipliers reduces the incentive for public interest litigants to bring the risky or complex cases which often produce the greatest external benefits by developing new areas of law.

Proponents of restrictions on fee awards maintain that such prohibitions pro-

80. See, e.g., Palmigiano v. Garrahy, 616 F.2d 598 (1st Cir. 1980); Oldham v. Ehrlich, 617 F.2d 163 (8th Cir. 1980); Serrano v. Unruh, 32 Cal. 3d 621, 652 P.2d 985, 186 Cal. Rptr. 754 (1982).

81. Blum v. Stenson, 512 F.Supp. 680 (S.D.N.Y.), affd, 671 F.2d 493 (2d Cir. 1981), cert. granted, 103 S.Ct. 2426 (1983).

82. A study comparing the earnings of public interest attorneys with those of their counterparts in private law firms found that the earnings of public interest lawyers were only $59 \%$ as high as they would have been in private practice. Komesar \& Weisbrod, The Public Interest Law Firm: A Behavioral Analysis, in Public InTEREST LAW, supra note 10 , at 80,82

83. One element of the latest Reagan Administration proposal is a provision designed to win support from lawyers compensated under the Criminal Justice Act, 18 U.S.C. $\S 3006 A$ (d)(1)-3006A(d) (2), for handling the defense of indigents in criminal cases. The proposal would double the maximum hourly rates specified by statute for Criminal Justice Act cases from $\$ 30 /$ hour to $\$ 60 /$ hour for time spent in court and from $\$ 20 /$ hour to $\$ 40 /$ hour for time spent out of court. Everyone agrees that the current ceilings set by the Criminal Justice Act are horrendously out of date. This illustrates the dangers of fee caps that do not adjust for inflation. Nonetheless the Administration is proposing to impose a flat $\$ 75 /$ hour cap on all fee awards, which would not permit adjustments for inflation, despite the fact that the Equal Access to Justice Act's $\$ 75 /$ hour cap permits such adjustments. Moreover, the Administration's justification for setting a lower cap ( $\$ 60 /$ hour) on Criminal Justice Act fees than for all other fee awards $(\$ 75 /$ hour $)$ is that Criminal Justice Act attorneys are compensated whether or not they are successful on the merits. 1983 Reagan Proposal, supra note $8, \S 5$. This same rationale would justify fees for public interest litigants at rates that are higher than that based on the salaries of government attorneys.

Using the Reagan Administration's assumption of overhead (three times take-home income) and 1,500 hours billing per year, a $\$ 75 /$ hour cap would imply a maximum take-home pay of $\$ 37,500$ for an attorney who always prevails regardless of the attorney's experience, the complexity of the litigation, or market rates in the community. This amount is less than the starting salary of recent law school graduates in some cities and in many cases less than the rates paid by governmental bodies hiring outside counsel. See Letter from the Alliance for Justice to Deputy Attorney General Edward C. Schmults (Sept. 28, 1983) (on file).

84. In practice, public interest attorneys often settle for fees at rates substantially below the market in return for prompt payment without the need for litigation over fee recovery. Proposals to restrict "fees on fees" (awards of attorney fees for time spent in litigation to recover fees) would be particularly damaging to public interest litigants because of lengthy delays in fee recovery litigation and the federal government's current practice of litigating virtually all fee requests. 
vide windfalls that unfairly subsidize public interest groups who pay low salaries to their staff attorneys. It is rare, however, that public interest groups ever recover their full litigation expenses from fee awards. Moreover, public interest lawyers spend much of their time on activities that do not generate eligibility for fee awards, such as participation in administrative proceedings prior to litigation. Even in the rare instance in which a fee award to a public interest organization exceeds the organization's actual litigation expenses, the award can only be used to fund further public interest activity ${ }^{85}$ Therefore, rather than providing private windfalls, fee awards at market rates simply permit public interest organizations to provide greater services than awards computed on a cost-plus basis.

Arguments that fee awards are grossly excessive are oft-repeated but never supported by any systematic statistical data. Anecodotal data appear to be the exclusive source for claims by the Reagan Administration that an entire "cottage industry" has been created by attorney fee awards to public interest groups. ${ }^{86}$ In fact, the federal government has not gathered any data indicating the total amount of attorney fee awards paid by the government in any given year.

One of the few sources of statistical data on attorney fee awards paid by the federal government is the annual report by the Administrative Office of the U.S. Courts dealing with experience under the Equal Access to Justice Act. Although government budget officials predicted that between 2,000 and 3,500 attorney fee awards totalling $\$ 125-500$ million would be awarded against the federal government in the first full year of experience under this Act, ${ }^{87}$ in fact, only fifty-two awards, worth a total of $\$ 1.7$ million, were made..$^{88}$

Data from public interest organizations indicates that attorney fee awards remain only a small percentage of the budget of most such groups. In 1976, a survey of the nation's public interest organizations found that attorney fee awards provided only $1 \%$ of the groups' total income between 1972 and $1975 .{ }^{89}$ While fee awards have become more significant with the enactment of additional fee shifting statutes in recent years, a 1983 survey of two dozen national public interest organizations found that during the 1979-1983 period, $70 \%$ of the organizations received less than $10 \%$ of their budgets in fee awards. ${ }^{90}$ Fee awards were a more significant, though still not predominant, share of the budget of the other organizations which

85. Internal Revenue Service regulations require a public interest organization to use court-awarded fees "exclusively for the purpose of defraying its normal operating expenses." Rev. Proc. 75-13, § 3.04, 1975-1 C.B. 662. Staff attorneys for public interest organizations must be compensated "on a straight salary basis, not exceeding reasonable salary levels and not established in reference to any fees recovered." Id. §3.05. Thus, the argument that fee caps are necessary to prevent attorneys working for public interest organizations from receiving greater compensation than government litigants is simply false.

86. The current draft Reagan Administration proposal includes a proposed finding that excessive fee awards have been made in many instances and that the fee shifting statutes have "often operated to oversubsidize attorneys at the expense of federal, state and local government taxpayers." 1983 Reagan Proposal, supra note $8, \S 2(\mathrm{a})(1)$.

87. See Awards of Attomeys' Fees Against the Federal Govemment: Hearings before the House Judiciary Comm., 96th Cong., 2d Sess. 474 (1980) (statement of Raymond S. Calamaro, Deputy Asst. Attorney General).

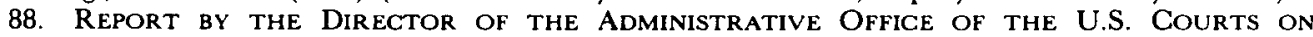

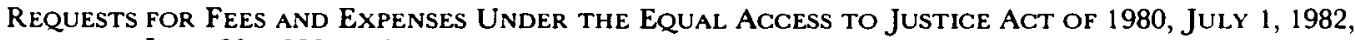
THROUGH JUNE 30, 1983, at 3-4 (1983).

89. Council FOR PUBlic INTEREST LAW, supra note 27, at D-10.

90. Alliance for Justice (unpublished survey findings) (1983). 
were active primarily in the civil rights area. Thus, court-awarded fees are a useful supplement to the budgets of public interest groups, but not a massive subsidy of their activities.

\section{$\mathrm{V}$ \\ CONCLUSION}

By authorizing fee shifting in favor of public interest litigants, Congress intended to reduce economic disincentives discouraging public interest litigation in order to further the enforcement of important public policies. The evidence does not suggest that Congress went too far in removing disincentives facing public interest litigants. The availability of fee awards encourages meritorious public interest litigation that furthers private enforcement of important public policies. Because the Reagan Administration's proposal severely curtailing fee awards to public interest litigants does not suggest any alternative means for achieving the Congressional purpose, it can only be motivated by the Administration's ideological antipathy to public interest litigation rather than by a concern for designing a more efficient means of providing equal access to justice. 
